særskilt annleis enn det ho er i dag, der mange eldre kjem inn med ei liste over reseptane sine der personnummer, namn og alle legemiddel er påført.

Innan ein finn ein god måte å løyse utfordringane med e-reseptar på, er det viktig at pasientar (og professorar i informatikk) har tillit til at alt helsepersonell, også apotektilsette, gjer det dei kan for å ivareta både personvern og pasienttryggleik i systemet vi har i dag.

Lillan Mo Andreassen

lillan.andreassen@isf.uib.no

Lone Holst

Reidun L.S. Kjome

Kristine Heitmann

Lillan Mo Andreassen (f. 1985) er msc.pharm. og stipendiat ved Forskningsgruppe for samfunnsfarmasi, Institutt for samfunnsmedisinske fag, Universitet i Bergen. Ho har tidlegare arbeidd i full stilling i apotek, og arbeider framleis deltid i apotek ved sida av doktorgradsarbeidet. Ingen oppgjevne interessekonfliktar.

Lone Holst (f. 1963) er cand.pharm., ph.d. og førsteamanuensis ved Forskningsgruppe for samfunnsfarmasi, Institutt for samfunnsmedisinske fag, Universitetet i Bergen. Ho har tidlegare arbeidd ti år i sjukehusapotek.

Ingen oppgjevne interessekonfliktar.

Reidun Lisbet Skeide Kjome (f. 1977) er cand.pharm., ph.d. og postdoktor ved Forskningsgruppe for samfunnsfarmasi, Institutt for samfunnsmedisinske fag, Universitetet i Bergen.

Ingen oppgjevne interessekonfliktar.

Kristine Heitmann (f. 1982) er msc.pharm. og stipendiat ved Forskningsgruppe for samfunnsfarmasi, Institutt for samfunnsmedisinske fag, Universitet i Bergen. Ho har tidlegare arbeidd i full stilling i apotek. Ingen oppgjevne interessekonfliktar.

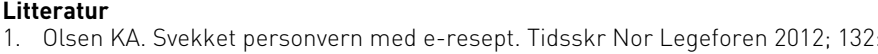
2363.
}

Publisert som rask respons på nett 12.11. 2012

\section{Elektroniske resepter og samhandling}

Ordningen med elektroniske resepter (e-resepter) innføres nå i Norge og skal være i bruk i hele landet i 2013. Hver dag ekspederes ca. 100000 resepter fra norske apotek. Nye systemer vil alltid kreve tilvenning og omstilling hos brukerne, i dette tilfellet leger, apotek og kunder/pasienter.

Allerede i 2007 uttalte Legeforeningen at innføring av elektroniske resepter ville kunne støtte opp under kvalitet og effektivitet i reseptbehandlingen (1). Det er sørgelig at Kai A. Olsen i sitt innlegg i Tidsskriftet nr. 21/2012 reiser tvil om det apotekfaglige personellets håndtering av e-resepter og taushetsplikten knyttet til dette og slik viser at han ikke har tillit til dem (2).

Elektroniske resepter har mange fordeler, spesielt med tanke på å sikre rasjonell legemiddelbruk for den enkelte og for samfunnet generelt. Enhver som er autorisert helsepersonell skal bidra til sikkerhet for pasientene og kvalitet i helsetjenesten, inkludert det å bygge opp tillitsforhold mellom helsepersonellet og brukerne av helsetjenesten (3).

Olsen mistenkeliggjør helsepersonellet i apotek og hevder deres resepthåndtering vil kunne føre til at opplysninger om folks helse og legemiddelbruk siver ut (2). Men helsepersonell i apotek har taushetsplikt! Ved innføring av e-resept vil samtlige apotek være tilknyttet helsenettet, noe som vil føre til nye samhandlingsmetoder mellom rekvirent og kunde. Her ligger det selvfølgelig utfordringer i det å ivareta gjeldende krav til personvern- og informasjonssikkerhet samt å samarbeide og ha tillit til hverandre - til pasientenes beste. Helsepersonell bevisstgjøres i stor grad på å ivareta sine plikter på dette området - det er utarbeidet en norm for informasjonssikkerhet (Normen) og en veileder for apotekene (4).

Et åpent system av e-resepter vil gjøre at apotekfarmasøytene kan bidra til sikrere legemiddelbruk. Ved å få en fullstendig oversikt over pasientens legemiddelbruk kan farmasøyten oppdage uheldige interaksjoner. For å sikre optimal behandling er kommunikasjon og samhandling mellom leger og farmasøyter en forutsetning (5-7).

Vår oppgave i Helse-Norge er å sikre riktig og forsvarlig legemiddelbruk til beste for pasientene i et samarbeid mellom pasienter og leger og farmasøyter - et viktig skritt i retning av fremtidens helsetjenester: Trygghet for alle.

\section{Grethe Sørgaard}

grethe.sorgaard@hioa.no

Cecilie Johannessen Landmark

Grethe Sørgaard er høyskolelektor ved Institutt for farmasi og bioingeniørfag, Fakultet for helsefag, Høgskolen i Oslo og Akershus. Ingen oppgitte interessekonflikter.

Cecilie Johannessen Landmark er dr.scient. og førsteamanuensis ved Høgskolen i Oslo og Akershus.

Ingen oppgitte interessekonflikter.

\section{Litteratur}

1. Heilemann A. Elektronisk reseptforsendelse gir utfordringer. Tidsskr Nor Lægeforen 2007; 127: 2862.

2. Olsen KA. Svekket personvern med e-resept. Tidsskr Nor Legeforen 2012; 132 2363.

3. Grimsmo A. Elektronisk resept - uten bivirkninger? Tidsskr Nor Lægeforen 2006: 126: 1740-3.

4. Helsedirektoratet. Personvern og informasjonssikkerhet for apotek - en veileder. Versjon 1. Oslo: Helsedirektoratet, 2012. www.normen.no (16.11.2012).

5. Lagerløv P, Nordeng H. Samhandling mellom fastlege og apotek. Tidsskr Nor Legeforen 2009; 129: 1844

6. Mandt I, Horn AM, Granås AG Samhandling mellom allmennleger og apotek ved korreksjon av resepter. Tidsskr Nor Legeforen 2009; 129: 1846-9.

7. St.meld. nr. 47 (2008-2009). Samhandlingsreformen. www.regjeringen.no/nb/dep/hod/dok/regpubl/stmeld/2008-2009/stmeld-nr-472008-2009-/14.html?id=567347 (16.11.2012).

Publisert som rask respons på nett 16.11. 2012.

\section{K.A. Olsen svarer:}

Jeg har ikke påstått at apotekansatte er «uærlige snokere som ikke vet å skjøtte jobben sin rett». Mitt poeng er at det er risikofylt å gi 7000 nye personer adgang til sentrale helseopplysninger. Nå har selvfølgelig apotekansatte taushetsplikt, men vi kan ikke løse personvernproblemer med å gi alle adgang så sant de underskriver en erklæring om taushetsplikt. Skal helseopplysninger virkelig være konfidensielle, må tilgangen begrenses til et minimum av personer.

Vi har allerede eksempler på leger og annet helsepersonell som «snoker» i arkivene. Mange blir tatt av elektroniske overvåningssystemer som plukker ut mistenkelige oppslag, for eksempel fra en lege som ikke er tilknyttet pasienten. Men som jeg har påpekt, vil det kunne være mange feilkilder i kommunikasjonen mellom kunde og apotekansatt. Dette vil medføre at det ikke vil være like lett å oppdage misbruk av tilgang her som andre steder.

Selv ønsker jeg ikke å tilby mine helseopplysninger til nye grupper. Derfor vil jeg velge å bruke låst resept. Den kan, som jeg sier, i sin enkleste form være identifisert med en kode på mobilen. 